\title{
DNA BARCODE FOR THE PARTHENOGENETIC SURINAM COCKROACH Pycnoscelus surinamensis (Linnaeus, 1758) (Blattodea: Blaberidae) FROM INDIA
}

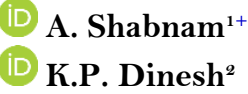

\author{
${ }^{1,2}$ Zoological Survey of India, Western Regional Centre, Vidya Nagar, \\ Maharashtra, India. \\ 'Email:shabnamansari9113@gmail.com Tel:020-27651927 \\ Email: kpdinesh.zsi@gmail.com Tel:020-27651927
}

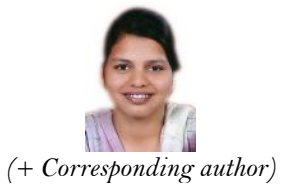

\section{Article History}

Received: 10 August 2021 Revised: 6 December 2021 Accepted: 24. December 2021 Published: 13 January 2022

\section{Keywords}

Surinam cockroach Greenhouse cockroach DNA barcode Western Ghats.

\section{ABSTRACT}

DNA Barcoding is one of the emerging tools in molecular identification of faunal diversity, specifically insect fauna. The Surinam cockroach, Pycnoscelus surinamensis is the only known roach to be obligatorily parthenogenetic, with reported haplotypes. $P$. surinamensis is well established in Indomalayan, tropical and subtropical regions and substantially documented from India with a phenetic approach. Herewith we report the first set of mt DNA barcode from a vouchered collection for the species from southern Western Ghats India. Discussions are made on the identity of two sequences each of Blatteria species and Pycnoscelus species reported from USA.

Contribution/Originality: This study contributes to the existing literature of Pycnoscelus surinamensis species from India with additional DNA barcode data from vouchered specimens for the species as well as the genus from the Western Ghats. Barcodes linked with the vouchered specimens forms the authenticated DNA reference library having utility in metabarcoding.

\section{INTRODUCTION}

In the trending era of 'DNA barcoding', the utility of short DNA stretches manifesting nucleotides divergence amongst species renders an intangible aid for precise identification and documentation of various life forms [1-3]. This nucleotide-based taxonomic research tool [3] have remarkably increased the pace of taxonomic discoveries facilitating access to Linnaean taxonomy for the experts and non-experts (for e.g. [4, 5]). Additionally, its usage has allowed the study of multifaceted heterogeneous questions outlining numerous paradigms [6]. Hebert's group [1] suggested the mitochondrial Cytochrome C oxidase subunit I gene ( $\mathrm{mt}$ COI) as a barcode gene for the delimitation of animal taxa and it is widely accepted for delimitation of different invertebrate groups including Blattodea [1,2]. Identification based on DNA barcodes solemnly depends on the DNA barcode reference library, whose caliber increases when the DNA barcodes are affiliated to a taxonomically identified vouchered specimen.

The order Blattodea is composed of roaches and termites [2, 7] of which roaches have a cosmopolitan distribution. Cockroaches are among the highly diverse insect groups with 4600 species/subspecies globally and 181 species in India [8] of which only 33 species ( 18\%) have DNA barcode data. The genus Pycnoscelus Scudder, 1862 is denoted by 15 species of which four species are known from India, Pycnoscelus indicus [9]; Pycnoscelus nigra [10]; Pycnoscelus surinamensis [11] and Pycnoscelus tenebrigera [12-14].

The species Pycnoscelus surinamensis belongs to the second largest cockroach family Blaberidae. It is an introduced species to India identified to have medical and economic importance $[15,16]$, native to the Sunda 
Islands of the Malaya Archipelago with a predominant range of distribution in the Indomalayan region [16, 17]. The species has recently invaded large parts of the tropical as well as subtropical regions of the world due to human intrusions [15-17]. P. surinamensis is reported to have many parthenogenetic clonal forms from different regions including Florida, Australia, Panama, Hawaii, and Indonesia [18, 19]. The Surinam cockroach is known as peridomestic species worldwide $[15,17]$ and acts as plants pest, biological vector, and is known for ecological associations [15].

The species P. surinamensis is thought to have evolved from its bisexual intimate progenitor P. indicus for rapid establishment $[16,18,19]$. GenBank searches suggest no DNA Barcode data is available for the members of Pycnoscelus from India. Hence, as a part of our exercise to generate mt DNA barcodes and documentation of species diversity from the Western Ghats, we report the first mt DNA barcode for the species $P$. surinamensis from southern Western Ghats, India with a vouchered specimen deposited at the National Zoological Collections (NZC).

\section{MATERIAL AND METHODOLOGY}

Three specimens were collected below the leaf litter during the daytime from the Courtallam forest (N 8.9331; E 77.2674), Tamil Nadu, India on 26.viii.2019 by K.P. Dinesh and Party. Specimens were fixed and preserved in $70 \%$ alcohol for further studies. Images were procured using DSLR camera Figure 1. For molecular studies, tissue was derived from leg and thoracic muscles. Studied examples are deposited in the National repository of Zoological Survey of India, Western Regional Centre, Pune, Maharashtra, India with the register number ZSI/WRC/Ent$12 / 81$.

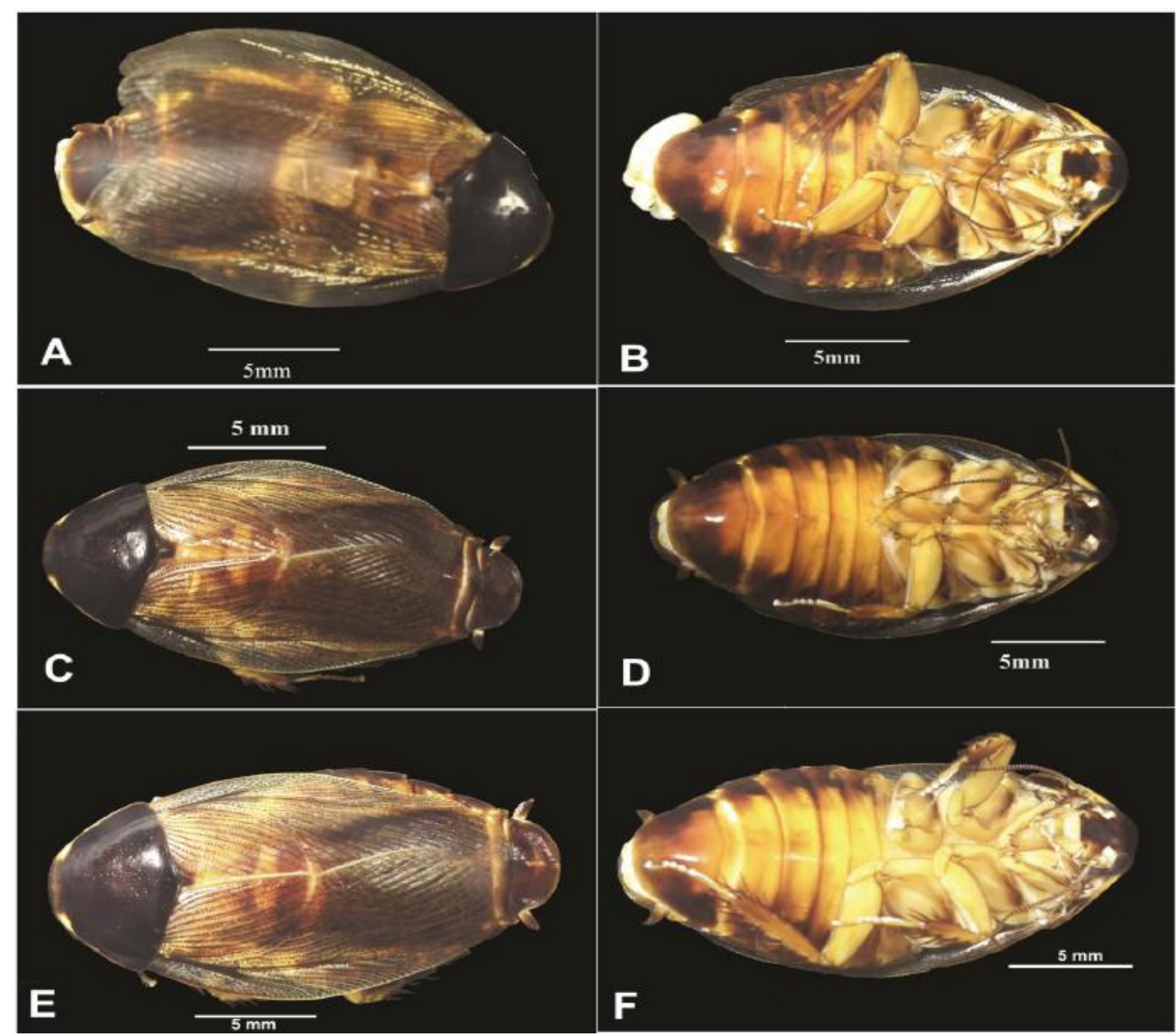

Figure 1. Pycnoscelus surinamensis from Courtallam forest, Tamil Nadu, India (A: Dorsal and 1 B: Ventral side of ZSI/WRC/Ent-12/81a; C: Dorsal and D: Ventral side of ZSI/WRC/Ent-2 12/81b; E: Dorsal and F: Ventral side of ZSI/WRC/Ent-12/81c). 
Genomic DNA extraction and purification were completed by the DNeasy Blood and Tissue Kit (Qiagen) as per the manufacturer's protocol from the alcohol preserved tissue samples. The eluted DNA was quantitated by Qubit 2.0 fluorometer ds DNA HS Assay. PCR amplification was performed using universal COI primers, LCO1490: 5'GGTCAACAAATCATAAAGATATTGG-3' and HCO2198: 5'-TAAACTTCAGGGTGACCAAAAAATCA-3' [20] in $25 \mu \mathrm{L}$ reaction volume consisting of $12.5 \mu \mathrm{L}$ of Go Taq Hot Start Green Master mix (Promega) $2 \mu \mathrm{L}$ (100ng) of genomic DNA, $1 \mu \mathrm{L}(10 \mathrm{pmol})$ of each primer and nuclease-free water up to Q.S. The thermal cycling profile was as per [1]. The amplified PCR product was verified on $1 \%$ agarose gel by electrophoresis stained by EtBr dye and visualized below UV light through Gelstain gel documentation system. Amplified PCR product was purified using Invitrogen's Pure Link PCR Purification Kit. Purified PCR product was sequenced bidirectionally by Sanger's method on ABI 377 (Applied Biosciences) sequencer.

\section{RESULT AND DISCUSSION}

The obtained sequences were manually verified for corrections and the mt COI gene sequences available for the species of Pycnoscelus were downloaded from the GenBank Table 1 and were aligned by Clustal W in MEGA X software [21]. For phylogenetic reconstruction, the Maximum Likelihood tree was built with RaxML [22] under the GTR+GAMMA+I model, with 1000 bootstrap replicates and the final consensus tree was visualized by FigTree v1.4.0 treating species of the closest subfamily as outgroups.

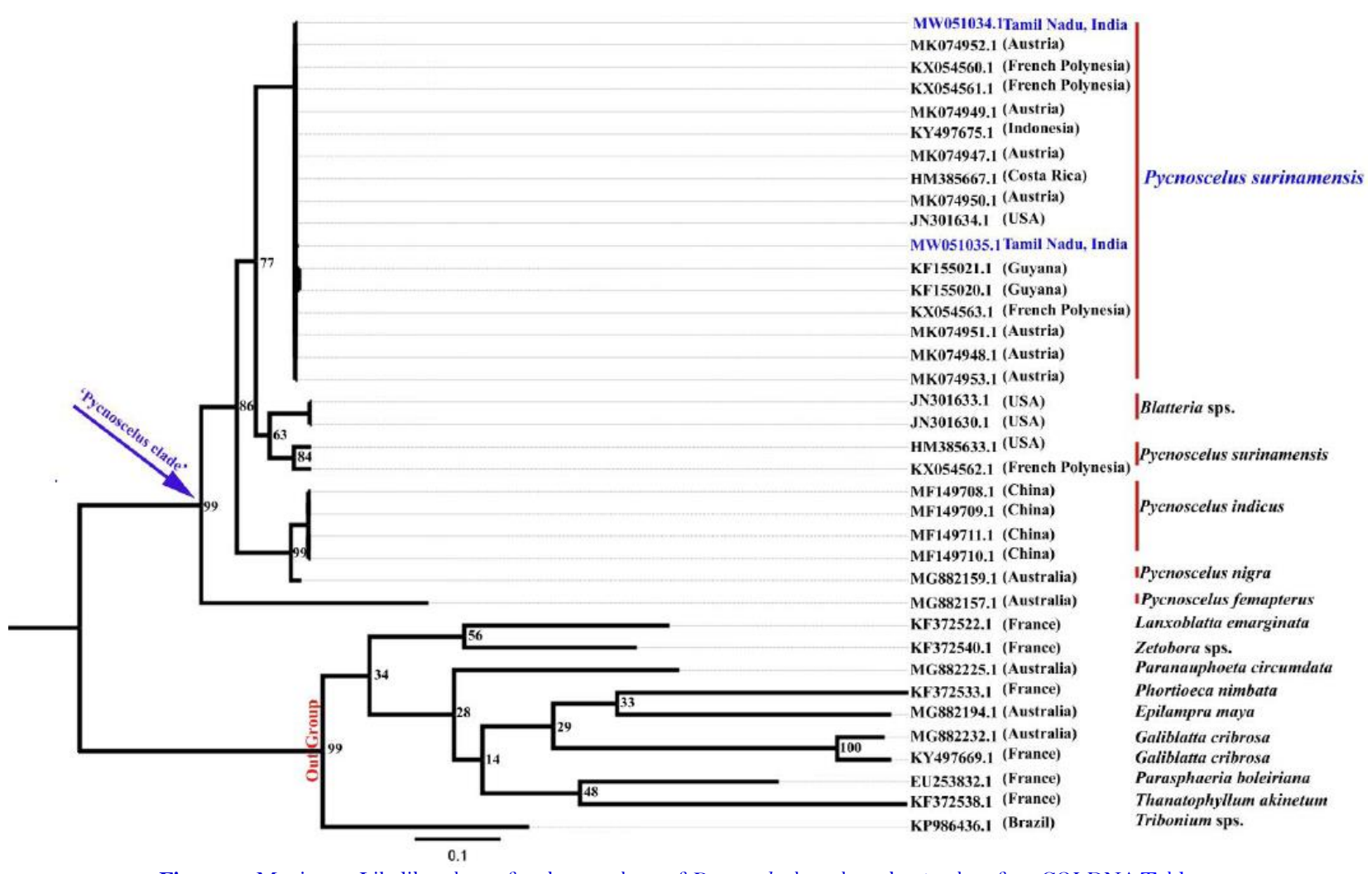

Figure 2. Maximum Likelihood tree for the members of Pycnoscelus based on the 588 bp of mt COI DNA Table 1.

Species identity was confirmed as Pycnoscelus surinamensis based on the Basic Local Alignment Search Tool (BLAST) search of National Center for Biotechnology Information (NCBI) (https://www.ncbi.nlm.nih.gov/) with $100 \%$ match for the DNA barcodes generated in our study. In the preliminary phylogenetic tree our samples formed a monophyletic clade Figure 2 with Pycnoscelus surinamensis sequences reported from China, Indonesia, Austria, and USA Table 1 complying with parthenogenesis. The P. surinamensis clade Figure 2 had specimen representations from, India, Austria, French Polynesia, Indonesia, Costa Rica, USA, and Guyana supporting the distribution range 
of the species to be cosmopolitan. The two sequences (HM385633.1, KX054562.1) from the USA were making a separate sub-clade. Additionally, JN301633.1 from the USA forms a sub-clade with JN301630.1 from French Polynesia Figure 2 intimating potential haplotypic forms of Pycnoscelus surinamensis.

Table 1. mt COI DNA sequences used for building Maximum Likelihood tree.

\begin{tabular}{|c|c|c|c|c|}
\hline Sr no. & $\begin{array}{l}\text { Gen Bank Acc. } \\
\text { No }\end{array}$ & Locality & $\begin{array}{l}\text { Species name as per Gen } \\
\text { Bank }\end{array}$ & $\begin{array}{l}\text { Publication details } \\
\text { as per NCBI }\end{array}$ \\
\hline 1 & MW051034.1 & Tamil Nadu, India & Pycnoscelus surinamensis & This study \\
\hline 2 & MKo74952.1 & Austria: Vienna & Pycnoscelus surinamensis & Zangl, et al. [23] \\
\hline 3 & KX054560.1 & French Polynesia & Pycnoscelus surinamensis & Ramage, et al. [24] \\
\hline 4 & KX054561.1 & French Polynesia & Pycnoscelus surinamensis & Ramage, et al. [24] \\
\hline 5 & MKo74949.1 & Austria: Styria & Pycnoscelus surinamensis & Zangl, et al. [23] \\
\hline 6 & KY497675.1 & Indonesia: Sumba island & Pycnoscelus sps. & Unpublished \\
\hline 7 & MKo74947.1 & Austria: Styria & Pycnoscelus surinamensis & Zangl, et al. [23] \\
\hline 8 & HM385667.1 & Costa Rica & Pycnoscelus surinamensis & Unpublished \\
\hline 9 & MKo74950.1 & Austria: Vienna & Pycnoscelus surinamensis & Zangl, et al. [23] \\
\hline 10 & JN301634.1 & USA & Pycnoscelus surinamensis & Unpublished \\
\hline 11 & MW051035.1 & Tamil Nadu, India & Pycnoscelus surinamensis & This study \\
\hline 12 & KF 155021.1 & Guyana & Pycnoscelus sps. & Unpublished \\
\hline 13 & KF 155020.1 & Guyana & Pycnoscelus sps. & Unpublished \\
\hline 14 & KX054563.1 & French Polynesia & Pycnoscelus. surinamensis & Ramage, et al. [24] \\
\hline 15 & MK074951.1 & Austria: Vienna & Pycnoscelus surinamensis & Zangl, et al. [23] \\
\hline 16 & MKo74948.1 & Austria: Styria & Pycnoscelus surinamensis & Zangl, et al. [23] \\
\hline 17 & MKO74953.1 & Austria: Vienna & Pycnoscelus surinamensis & Zangl, et al. [23] \\
\hline 18 & JN301633.1 & USA & Pycnoscelus surinamensis & Unpublished \\
\hline 19 & JN301630.1 & USA & Pycnoscelus surinamensis & Unpublished \\
\hline 20 & HM385633.1 & USA & Pycnoscelus surinamensis & Unpublished \\
\hline 21 & KX054562.1 & French Polynesia & Pycnoscelus surinamensis & Ramage, et al. [24] \\
\hline 22 & MF 149708.1 & China & Pycnoscelus indicus & Ma, et al. [25] \\
\hline 23 & MF 149709.1 & China & Pycnoscelus indicus & Ma, et al. [25] \\
\hline 24 & MF 149711.1 & China & Pycnoscelus indicus & Ma, et al. [25] \\
\hline 25 & MF 149710.1 & China & Pycnoscelus indicus & Ma, et al. [25] \\
\hline 26 & MG882159.1 & Australia & Pycnoscelus nigra & $\begin{array}{l}\text { Bourguignon, et al. } \\
{[26]}\end{array}$ \\
\hline 27 & MG882157.1 & Australia & Pycnoscelus femapterus & $\begin{array}{l}\text { Bourguignon, et al. } \\
{[26]}\end{array}$ \\
\hline 28 & KF372522.1 & France & Lanxoblatta emarginata & Legendre, et al. \\
\hline 29 & KF372540.1 & France & Zetobora sps. & $\begin{array}{l}\text { Legendre, et al. } \\
{[27]}\end{array}$ \\
\hline 30 & MG882225.1 & Australia & Paranauphoeta circumdata & $\begin{array}{l}\text { Bourguignon, et } \\
\text { al. [26] }\end{array}$ \\
\hline 31 & KF372533.1 & France & Phortioeca nimbata & $\begin{array}{l}\text { Legendre, et al. } \\
{[27]}\end{array}$ \\
\hline 32 & MG882194.1 & Australia & Epilampra maya & $\begin{array}{l}\text { Bourguignon, et } \\
\text { al. [26] }\end{array}$ \\
\hline 33 & MG882232.1 & Australia & Galiblatta cribrosa & $\begin{array}{l}\text { Bourguignon, et } \\
\text { al. [26] }\end{array}$ \\
\hline 34 & KY497669.1 & France & Galiblatta cribrosa & Unpublished \\
\hline 35 & EU253832.1 & France & Parasphaeria boleiriana & $\begin{array}{l}\text { Legendre, et al. } \\
{[28]}\end{array}$ \\
\hline 36 & KF372538.1 & France & Thanatophyllum akinetum & $\begin{array}{l}\text { Legendre, et al. } \\
{[27]}\end{array}$ \\
\hline 37 & KP986436.1 & Brazil & Tribonium sps. & $\begin{array}{l}\text { Legendre, et al. } \\
\text { [29] }\end{array}$ \\
\hline
\end{tabular}


The species Pycnoscelus surinamensis is sufficiently documented in India from the states Andhra Pradesh, Arunachal Pradesh, Chhattisgarh, Delhi, Manipur, Karnataka, Maharashtra, Meghalaya, Orissa, Rajasthan, Sikkim, Tamil Nadu, Tripura, and West Bengal $[8,12,13]$ based on morphological studies and checklists without any genetic or DNA barcode data. Therefore, the occurrence of any potential haplotype or genetic variant for the parthenogenetic species is yet unexamined. As the evolution of thelytokous parthenogenenis is understudied the Pycnoscelus taxon is complicated to understand [18]. Therefore, the contribution of molecular data in this particular taxon is of immense value for delimiting the species complex and their evolutionary history.

The present report of Pycnoscelus surinamensis Figure 1 from Courtallam forest (Tamil Nadu) forms the first vouchered based DNA barcode record for the species as well as for the genus from India. To precisely validate the occurrence of any potential haplotype or genetic variant, large-scale DNA-based molecular studies are warranted. The current DNA barcode data generated for Pycnoscelus surinamensis from India forms baseline data for the DNA barcoding archives of the species and is expected to have utility in taxonomy, systematics, and metabarcoding other than biodiversity documentation.

Funding: This study received no specific financial support.

Competing Interests: The authors declare that they have no competing interests.

Acknowledgement: The authors are grateful to the Director, Zoological Survey of India, Kolkata; the Officer-in-Charge, Zoological Survey of India, Western Regional Centre, Pune for the research facilities and support. We thank Dr. Sameer Kumar Pati, Zoological Survey of India, Western Regional Centre, Pune for help in photography. We acknowledge the help of the staff of ZSI, WRC, Pune for the lab and field support. We thank Ms. Sangetha Devi and Ms. Sayali Aspate, Modern College of Arts, Commerce and Science, Shivajinagar, Pune, for their help in the wet lab.

\section{REFERENCES}

[1] P. D. Hebert, S. Ratnasingham, and J. R. De Waard, "Barcoding animal life: Cytochrome c oxidase subunit 1 divergences among closely related species," Proceedings of the Royal Society of London. Series, vol. 270, pp. S96-S99, 2003.

[Q] D. Inward, G. Beccaloni, and P. Eggleton, "Death of an order: A comprehensive molecular phylogenetic study confirms that termites are eusocial cockroaches," Biology Letters, vol. 3, pp. 331-335, 2007.Available at: https://doi.org/10.1098/rsbl.2007.0102.

[3] P. Z. Goldstein and R. DeSalle, "Integrating DNA barcode data and taxonomic practice: Determination, discovery, and description," Bioessays, vol. 33, pp. 135-147, 2011 .Available at: https://doi.org/10.1002/bies.201000036.

[4] A. S. Kalawate, K. P. Dinesh, and A. Shabnam, "DNA barcoding unravels three new species and a subspecies of Olepa Watson, 1980 (Lepidoptera, Erebidae, Arctiinae) from India, with morphotypes," Journal of Insect Biodiversity, vol. 19, pp. 44-60, 2020.Available at: https://doi.org/10.12976/jib/2020.19.2.2.

[5] A. S. Kalawate, S. Pawara, A. Shabnam, and K. P. Dinesh, "DNA barcode reveals the occurrence of Palearctic Olepa schleini Witt et al., 2005 (Lepidoptera: Erebidae: Arctiinae) from peninsular India with morphological variations and a new subspecies," Journal of Threatened Taxa, vol. 12, pp. 16143-16152, 2020.Available at: https://doi.org/10.11609/jott.5596.12.9.16143-16152.

[6] L. Sarvananda, "Short introduction of DNA barcoding," International Journal of Research in Medical Sciences, vol. 5, pp. $673-685,2018$.

[7] S. Kambhampati, "Phylogenetic relationship among cockroach families inferred from mitochondrial 12S rRNA gene sequence," Systematic Entomology, vol. 21, pp. 89-98, 1996.

[8] G. W. Beccaloni, "Cockroach species file (Version 5.0/5.0) [Online]. World Wide Web electronic publication. Retrieved from: http://Cockroach.SpeciesFile.org. [Accessed 10 May 2020]," 2014.

[9] J. C. Fabricius, Systema entomologiae, sistens insectorvm classes, ordines, genera, species, adiectis synonymis, locis, descriptionibvs, observationibvs: Flensbvrgi, Lipsiae. (Kort), 1775.

[10] B. von Wattenwyl, "New Blattarian system," 1865. 
[11] C. Linnæus, Systema nature per regna tria nature, secundum classes, ordines, genera, species, cum characteribus, differentiis, synonymis, locis. Tomus I. Editio decima, reformata. Holmiae: Curt, 1758.

[12] S. K. Gupta and K. Chandra, "An annotated checklist of cockroaches (Blattodea) from India," Zootaxa, vol. 4614, pp. 461-497, 2019.Available at: https://doi.org/10.11646/zootaxa.4614.3.3.

[13] S. Prabakaran, "Studies on the cockroach fauna of Karnataka (Insecta: Blattodea). Record," Zoological Survey of India, vol. 110, pp. 109-119, 2010.

[14] F. Walker, Catalogue of the specimens of Blattariae in the collection of the British museum: Trustees of the British Museum, 1868.

[15] T. De Carvalho Moretti, E. M. Quirán, D. R. Solis, M. L. Rossi, and P. J. Thyssen, "Pycnoscelus surinamensis (Linnaeus, 1758)(Blaberoidea: Blaberidae), a cockroach with a possible association with the ant Brachymyrmex cordemoyi Forel, 1895 (Hymenoptera: Formicidae) and which may be exhibiting a domiciliation trend," Symbiosis, vol. 53, pp. 37-39, 2011.Available at: https://doi.org/10.1007/s13199-010-0101-3.

[16] R. Pellens and P. Grandcolas, "Are successful colonizers necessarily invasive species? The case of the so-called invading parthenogenetic cockroach, Pycnoscelus surinamensis, in the Brazilian Atlantic forest," Revue D'écologie, vol. 57, pp. 253-26, 2002 .

[17] P. Grandcolas, A. Dejean, and P. Deleporte, "The invading parthenogenetic cockroach: A natural history comment on Parker and Niklasson's study," Journal of Evolutionary Biology, vol. 9, pp. 1023-1026, 1996.Available at: https://doi.org/10.1046/j.1420-9101.1996.9061023.x.

[18] L. M. Roth, "Sexual isolation in parthenogenetic Pycnoscelus surinamensis and application of the name Pycnoscelus indicus to its bisexual relative (Dictyoptera: Blattaria: Blaberidae: Pycnoscelinae)," Annals of the Entomological Society of America, vol. 60, pp. 774-779, 1967.Available at: https://doi.org/10.1093/aesa/60.4.774.

[19] L. M. Roth, "A Teratological Specimen of Pycnoscelus surinamensis," Annals of the Entomological Society of America, vol. 61, pp. 777-779, 1968.Available at: https://doi.org/10.1093/aesa/61.3.777.

[20] O. Folmer, W. R. Hoeh, M. B. Black, and R. C. Vrijenhoek, "Conserved primers for PCR amplification of mitochondrial DNA from different invertebrate phyla," Molecular Marine Biology and Biotechnology, vol. 3, pp. $294-299$, 1994.

[21] S. Kumar, G. Stecher, M. Li, C. Knyaz, and K. Tamura, "MEGA X: molecular evolutionary genetics analysis across computing platforms," Molecular Biology and Evolution, vol. 35, pp. 1547-1549, 2018.Available at: https://doi.org/10.1093/molbev/msy096.

[22] D. Silvestro and I. Michalak, "RaxmlGUI: a graphical front-end for RAxML," Organisms Diversity \& Evolution, vol. 12, pp. 335-337, 2012.

[23] L. Zangl, G. Kunz, C. Berg, and S. Koblmüller, "First records of the parthenogenetic Surinam cockroach Pycnoscelus surinamensis (Insecta: Blattodea: Blaberidae) for Central Europe," Journal of applied Entomology, vol. 143, pp. 308-313, 2019.Available at: https://doi.org/10.1111/jen.12587.

[24] T. Ramage, P. Martins-Simoes, G. Mialdea, R. Allemand, A. Duplouy, P. Rousse, and S. Charlat, "A DNA barcodebased survey of terrestrial arthropods in the Society Islands of French Polynesia: host diversity within the SymbioCode Project," European Journal of Taxonomy, vol. 272, pp. 1-13, 2017.Available at: https://doi.org/10.5852/ejt.2017.272.

[25] J. Ma, J. Liu, Y. Shen, Z. Fan, B. Yue, and X. Zhang, "Population genetic structure and intraspecific genetic distance of Periplaneta americana (Blattodea: Blattidae) based on mitochondrial and nuclear DNA markers," Ecology and Evolution, vol. 9, pp. 12928-12939, 2019.Available at: https://doi.org/10.1002/ece3.5777.

[26] T. Bourguignon, Q. Tang, S. Y. Ho, F. Juna, Z. Wang, D. A. Arab, S. L. Cameron, J. Walker, D. Rentz, and T. A. Evans, "Transoceanic dispersal and plate tectonics shaped global cockroach distributions: Evidence from mitochondrial phylogenomics," Molecular Biology and Evolution, vol. 35, pp. 970-983, 2018.Available at: https://doi.org/10.1093/molbev/msy013. 
[27] F. Legendre, C. A. D'Haese, P. Deleporte, R. Pellens, M. F. Whiting, K. Schliep, and P. Grandcolas, "The evolution of social behaviour in Blaberid cockroaches with diverse habitats and social systems: Phylogenetic analysis of behavioural sequences," Biological Journal of the Linnean Society, vol. 111, pp. 58-77, 2014.Available at: https://doi.org/10.1111/bij.12199.

[28] F. Legendre, M. F. Whiting, C. Bordereau, E. M. Cancello, T. A. Evans, and P. Grandcolas, "The phylogeny of termites (Dictyoptera: Isoptera) based on mitochondrial and nuclear markers: implications for the evolution of the worker and pseudergate castes, and foraging behaviors," Molecular Phylogenetics and Evolution, vol. 48, pp. 615-627, 2008.Available at: https://doi.org/10.1016/j.ympev.2008.04.017.

[29] F. Legendre, A. Nel, G. J. Svenson, T. Robillard, R. Pellens, and P. Grandcolas, "Phylogeny of Dictyoptera: Dating the origin of cockroaches, praying mantises and termites with molecular data and controlled fossil evidence," PloS One, vol. 10, p. e0130127, 2015.Available at: https://doi.org/10.1371/journal.pone.0130127.

Views and opinions expressed in this article are the views and opinions of the author(s), International Research Journal of Insect Sciences shall not be responsible or answerable for any loss, damage or liability etc. caused in relation to/arising out of the use of the content. 